CENTRE FOR EMEA BANKING, FINANCE \& ECONOMICS

The Euro Changeover and Price Adjustments in Italy

Guglielmo Maria Caporale

Alessandro Girardi

Marco Ventura

Working Paper Series

No 13/11 


\title{
The Euro Changeover and Price Adjustments in Italy
}

\author{
Guglielmo Maria Caporale $^{\mathrm{a},{ }^{*}}$, Alessandro Girardi ${ }^{\mathrm{b}, \mathrm{c}}$ and Marco Ventura ${ }^{\mathrm{c}}$

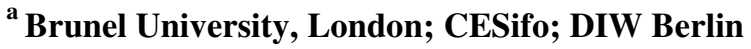 \\ ${ }^{b}$ Ministry of Economic Affairs and Finance, Rome, Italy \\ c Italian National Institute of Statistics, Rome, Italy
}

\begin{abstract}
By estimating a staggered price model over the period 1980q1-2010q2, this paper documents that, after the euro changeover, Italian retailers have increased the number of price adjustments, which has translated into a higher inflation rate, with a detrimental effect on the competitiveness of the Italian economy.
\end{abstract}

Keywords: Euro changeover, staggered price adjustments, inflation.

JEL classification: C22, E31.

* Corresponding author. Centre for Empirical Finance, Brunel University, West London UB8 3PH, UK.

Email: Guglielmo-Maria.Caporale@brunel.ac.uk 


\section{Introduction}

On the $1^{\text {st }}$ of January 1999, national currencies were replaced by the euro in eleven European countries. According to some economists, the switch to euro-denominated prices for goods and services (the euro changeover) did not amount to a mere change of the numeraire for current transactions: it could also have generated speculative behaviour, through the implicit coordination of price setters towards higher price equilibria, as a result of money illusion or market imperfections (Fehr and Tyran, 2001; 2007).

Although the possible effects of the euro changeover have been debated in all the countries that switched to euro denominated prices, this has been a particularly controversial issue in Italy, where it has involved consumers claiming that official statistics were not reporting the "true" inflation rate, the authorities and academics as well. Marini et al. (2007), among others, have argued that the combined effect of the introduction of the new currency and the existence of industries with market power could have produced self-fulfilling inflationary expectations leading to discontinuous price jumps totally unrelated to underlying market conditions or fundamentals.

A possible explanation for the difference between perceived and actual inflation is that consumers attach greater weight to price changes in goods and services bought more frequently relative to the so-called 'big ticket items', such as durable goods (ECB, 2003; Marini et al., 2007). Official inflation measures reflect instead the price changes faced by hypothetical average consumers, whose consumption basket matches the consumption structure of the economy as a whole. The present paper aims to provide some empirical evidence on whether there exists a changeover effect in the official inflation measure in the specific case of Italy.

In our view, quantifying the possible impact of the changeover effect amounts to identifying a discontinuity in sellers' pricing behaviour in the changeover period: since price adjustments 
are costly (Zbaracki et al. 2004; Bergen et al., 2008), a greater number of adjustments should imply an acceleration in inflation dynamics. For this purpose, we estimate a pricing function based on a staggered pricing model that has already been used successfully for the US (Galì and Gertler, 1999, Hall et al. 2000; Bakhsi et al 2007; Janko 2008). Our results document an increase in the average number of price changes, the euro changeover effect being found equal to around $40 \%$ of the inflation rate.

\section{Empirical Analysis}

\subsection{Theoretical underpinnings}

While in the rational expectations paradigm prices are perfectly flexible, in staggered pricing models (Fisher, 1977; Taylor, 1979; Calvo, 1983) they are adjusted by price setters towards optimising levels at discrete time intervals. Indeed, in the real world continuous re-optimising of price levels is not a viable option for firms, since it entails costs related to information gathering, evaluation, price decision and revision of the price list (Akerlof and Yellen, 1985; Akerlof, 2002).

A common feature of staggered price models is the inclusion of a constraint on the frequency of the price optimisation process, with the overall inflation rate being seen as the result of aggregating individual price setting decisions. This aggregation is greatly simplified by Calvo's approach (1983), which assumes that in a given period there is a fixed probability, $\theta$, that a firm will maintain its price constant. Therefore, in any given period the fixed probability that a price setter will adjust his price in the same period is $1-\theta$. Following the approach of Galì and Gertler (1999) and Eichenbaum and Fisher (2003), we estimate the following equation:

$$
E_{t}\left\{\left[\pi_{t}-\theta^{-1}(1-\theta)(1-\beta \theta) s_{t}-\beta \pi_{t+1}\right] z_{t}\right\}=0
$$


where $E_{t}$ is the expectation operator at time $t, \pi_{t}$ and $s_{t}$ represent (the deviation from the steady-state of) the inflation rate and real marginal costs, respectively, $\beta$ is the subjective discount rate, and $z_{t}$ is a set of instruments that must satisfy the orthogonality condition.

Testing whether inflation accelerated after the euro changeover implies testing that a smaller fraction of price setters kept their price unchanged, i.e. that $\theta$ was lower on average. In turn, this means a shorter average period during which prices are unchanged, as given by $\xi \equiv(1-\theta)^{-1}$. In order to capture possible changeover effects, we estimate equation (1) including a dummy variable, $D_{t}$, taking value 0 for the quarters between $1999 \mathrm{q} 1$ and $2003 \mathrm{q} 4$, and 1 otherwise, and then we test the constancy of $\theta$ over the different periods. ${ }^{1}$ The empirical model is therefore specified as follows:

$$
E_{t}\left\{\left[\pi_{t}-D_{t} \cdot \theta^{-1} \cdot(1-\theta) \cdot(1-\beta \theta) \cdot s_{t}-\left(1-D_{t}\right) \cdot \theta_{c}^{-1} \cdot\left(1-\theta_{c}\right) \cdot\left(1-\beta \theta_{c}\right) \cdot s_{t}-\beta \pi_{t+1}\right] z_{t}\right\}=0
$$

\subsection{Data and estimation results}

The data are taken from the OECD Main Economic Indicators database. The sample consists of quarterly observations over the period 1980q1-2010q2. We consider four alternative aggregate price series: 1) the Consumer Price Index (CPI), 2) the consumption expenditure deflator (CED), 3) the GDP deflator (GDPD), and 4) the Harmonized CPI (HCPI). Real marginal costs are computed as the logarithm of the wage share of GDP. Following Galì and Gertler (1999) and Eichenbaum and Fisher (2003), we use the sample period average for the four measures of inflation and for real marginal costs as a proxy for their respective steadystate values. As for the set of instruments, we include a constant term, labour income share, quadratically detrended real GDP, the spread between the annual interest rate on the ten-year

\footnotetext{
${ }^{1}$ Riaño et al. (2007), among others, identify the euro changeover in a similar way. The chosen ending period (namely, 2003q4) includes some delayed effect in sellers' price revisions. Similar results are obtained with the 1999q1-2004q4 window.
} 
Treasury bond and three-month Treasury bills, and the growth rate of the producer price index and of nominal wages. This corresponds to the basic set of instruments used in Gali and Gertler (1999).

GMM estimation results for equation (2) are presented in Table 1. A HAC Newey-West estimation weighting matrix was used (Greene, 2008). Given the difficulty of estimating $\beta$ with precision across the different inflation measures, we follow Eichenbaum and Fisher (2003) by setting this parameter equal to 0.99 .

\section{[Table 1]}

The comparison between $\theta$ and $\theta_{c}$ shows a sharp decrease in the share of firms keeping their retail prices fixed after the changeover, and this holds for each inflation measure. In the changeover period price changes occur after 1.1 quarters, a much lower value than in the previous period (i.e., 1.9 - 1.8 in the case of GDPD). The change in the value of $\theta$ implies an average increase in the number of adjustments per year, given by $\lambda \equiv 4 \cdot\left(\xi_{c}^{-1}-\xi^{-1}\right)$, ranging from 1.4 to 1.7 . Finally, the Wald test rejects the null of no break for all the inflation measures whilst the Sargan J statistics validates the set of instruments.

\subsection{Assessing the changeover effect}

In order to translate the extra number of adjustments made $(\lambda)$ into a quantitative estimate of the euro impact on actual inflation, we recall that price revisions entail "small menu costs" for firms. According to Levy et al. (1997), such costs amount to around 0.7\% of total annual revenues. Assuming that the cost of price adjustments represents at least this percentage of annual revenues, then during the changeover period total revenues should increase by at least 0.7 times $\lambda$ for sellers to break even. 
Total revenues can be written as $R_{t}=\bar{p}_{t} \cdot Q_{t}$ where $R_{t}$ is total revenues, $\bar{p}_{t}$ is the weighted average price and $Q_{t} \equiv \sum_{i} q_{i t}$, with $q_{i t}$ being the quantity of good $i$ at time $t$. The total differential of the log of total revenues is:

$$
d \ln \left(R_{t}\right)=\left(\dot{\bar{p}} / \bar{p}_{t}\right)+\left(\dot{Q}_{t} / Q_{t}\right)
$$

where the dot stands for the time derivative. The average rate of change of prices is equal to the difference between the rate of change in total revenues and the rate of change in quantities. With a negatively sloped demand curve, the rate of change in quantities is negative, becoming positive in the LHS of (3). Therefore, setting $\dot{Q}_{t} / Q_{t}=0$ will produce a conservative estimate of the euro changeover effect. Table 2 reports the estimate of the minimum value of the changeover effect calculated as 0.7 times the $\lambda$ 's.

\section{[Table 2]}

The estimated menu costs range from 1 to 1.2 percentage points and the changeover effect amounts from 38 to $49 \%$ of the official inflation rate, suggesting that the euro changeover has had a detrimental impact on the competitiveness of the Italian economy at an aggregate level. These figures are in contrast with the evidence previously reported by the ECB (2003), where the reported estimates of the changeover effect ranged between 0.1 and 0.3 percentage points.

\section{Conclusions}

Using an empirically testable version of a staggered price model, we document that a euro changeover effect occurred in Italy. Our estimates show that indeed the fraction of firms keeping their prices unchanged decreased after the changeover. In turn, this implies a euro 
changeover effect of about $40 \%$ of the inflation rate. As for criticism of the published statistics made by consumers, although it is correct to claim that there was a changeover effect, this is taken into account by the official inflation figures. All in all, the euro changeover has exerted a negative impact on the competitiveness of the Italian economy.

\section{References}

Akerlof G.A. (2002), Behavioral Macroeconomics and Macroeconomics Behavior, American Economic Review, 92, 411-433.

Akerlof G.A. and J. Yellen (1985), A Near Rational Model of the Business Cycle with Wage and Price Inertia, Quarterly Journal of Economics, 100, 823-838.

Bakhshi H., H. Khan and B. Rudolf (2007), The Phillips Curve under State-dependent Pricing, Journal of Monetary Economics, 54, 2321-2345

Bergen M., D. Levy, S. Ray, P.H. Rubin and B. Zeliger (2008), When Little Things Mean a Lot: On the Inefficiency of Item-Pricing Laws, Journal of Law and Economics, 51, 209250.

Calvo G. (1983), Staggered Prices in a Utility Maximizing Framework, Journal of Monetary Economics, 12, 383-398.

ECB (2003), Annual Report 2002, Frankfurt am Main.

Eichembaum M. and J.D.M. Fisher (2003), Testing the Calvo Model of Sticky Prices, Economic Perspective, 2Q, 40-53.

Fehr E. and J.T. Tyran, (2001), Does Money Illusion Matter?, American Economic Review, $91,1239-1262$.

Fehr E. and J.T. Tyran, (2007), Money Illusion and Coordination Failure, Games and Economic Behavior, 58, 246-268.

Fisher S. (1977), Long Term Contracts, Rational Expectations and the Optimal Money Supply Rule, Journal of Political Economy, 85, 191-205. 
Galì J. and M. Gertler (1999), Inflation Dynamics: A Structural Econometric Analysis, Journal of Monetary Economics, 44, 195-222.

Greene W.H. (2008). Econometric Analysis, 6th Edition, Upper Saddle River, NJ: PrenticeHall.

Hall S., A. Yates and M. Walsh (2000), Are UK Companies' Prices Sticky?, Oxford Economic Papers, 52, 425-446.

Janko Z. (2008), Nominal Wage Contracts, Labor Adjustment Costs and the Business Cycle, Review of Economic Dynamics, 11, 434-448.

Levy D., M. Bergen, S. Dutta and R. Venable R. (1997), The Magnitude of Menu Costs: Direct Evidence from Large US Supermarket Chains, Quarterly Journal of Economics, $112,791-825$.

Marini G., A. Piergallini and P. Scaramozzino (2007), Inflation Bias after the Euro: Evidence from the UK and Italy, Applied Economics 39, 461-470.

Riaño C., F.J. Ruiz and R. Santamaría (2007), Determinants of the Underpricing of New Shares during the Subscription Period: Empirical Evidence from the Spanish Stock Exchange, Applied Financial Economics, 17, 521-540.

Taylor J. (1979), Staggered Wage Settings in a Macro Model, American Economic Review Papers and Proceedings, 69, 108-113.

Zbarachi M.J., M. Ritson, D. Levy, S. Dutta and M. Bergen (2004), Managerial and Customer Cost of Price Adjustment: Direct Evidence from Industrial Markets, Review of Economics and Statistics, 86, 514-533. 


\begin{tabular}{|c|c|c|c|c|}
\hline & CPI & CED & GDPD & HCPI \\
\hline$\theta$ & $\begin{array}{c}0.4698 \\
(0.0099)\end{array}$ & $\begin{array}{c}0.4978 \\
(0.0176)\end{array}$ & $\begin{array}{c}0.4399 \\
(0.0155)\end{array}$ & $\begin{array}{c}0.4896 \\
(0.0095)\end{array}$ \\
\hline$\theta_{c}$ & $\begin{array}{c}0.0773 \\
(0.0063)\end{array}$ & $\begin{array}{c}0.0735 \\
(0.0061)\end{array}$ & $\begin{array}{c}0.0914 \\
(0.0172)\end{array}$ & $\begin{array}{c}0.0738 \\
(0.0047)\end{array}$ \\
\hline Wald test & {$[0.0000]$} & {$[0.0000]$} & {$[0.0000]$} & [0.0000] \\
\hline Sargan $\mathrm{J}$ test & {$[0.6950]$} & {$[0.5933]$} & {$[0.7224]$} & [0.5437] \\
\hline$\xi$ & 1.89 & 1.99 & 1.79 & 1.96 \\
\hline$\xi_{c}$ & 1.08 & 1.08 & 1.10 & 1.08 \\
\hline$\lambda=4 \cdot\left(\xi_{c}^{-1}-\xi^{-1}\right)$ & 1.59 & 1.69 & 1.40 & 1.66 \\
\hline
\end{tabular}

Note. The columns CPI, CED, GDPD, HCPI report the GMM estimation results for equation (2) in the main text where the inflation rate is calculated by using the Consumer Price Index, the consumption expenditure deflator, the GDP deflator and the Harmonized Consumer Price Index, respectively. The Wald test is for null hypothesis $H_{0}: \theta=\theta_{c} . \xi$ and $\xi_{c}$ are the quarters before price changes before and after the changeover, respectively. $\lambda$ is the difference between the annual number of price revisions made by sellers between the changeover and the non changeover period. Standard errors in parenthesis. $p$-values in square brackets. 
Table 2. Assessment of the euro changeover effect (1999q1-2003q4)

\begin{tabular}{ccccc}
\hline & CPI & CED & GDPD & HCPI \\
\hline Average inflation & 2.39 & 2.66 & 2.55 & 2.36 \\
Menu costs & 1.11 & 1.19 & 0.98 & 1.16 \\
(Changeover effect) & $(46.47)$ & $(44.56)$ & $(38.52)$ & $(49.34)$ \\
\hline
\end{tabular}

Note. See Table 1. Share of menu costs over the average actual inflation in parentheses. 